\title{
Community Perception and Adaptation to Safe Drinking Water Scarcity: Salinity, Arsenic, and Drought Risks in Coastal Bangladesh
}

\author{
Md. Anwarul Abedin • Umma Habiba • \\ Rajib Shaw
}

Published online: 21 June 2014

(C) The Author(s) 2014. This article is published with open access at Springerlink.com

\begin{abstract}
One of the most serious resource and health issues in coastal communities of Bangladesh is the scarcity of safe drinking water, triggered by the combined effects of salinity, arsenic, and drought. This article explores community perception of vulnerabilities in daily life, livelihood, and environment, and investigates how communities and institutions cope with or adapt to drinking water scarcity. This study outlines community expectations for support from government and nongovernment organizations to overcome this problem. The findings reveal that nearly all respondents from the drinking water scarcity area perceive that salinity is the primary reason for the lack of safe drinking water compared to arsenic and drought hazards. Despite a number of socioeconomic factors and a geographical location that aggravates the coastal communities' vulnerability, these communities have established their own adaptation mechanism to cope with this crisis. Government and nongovernment organizations have also supported community efforts to cope with the problem. By emphasizing both community adaptation methods and efforts of institutions, this article illustrates an integrated community-based approach, which would be effective for reducing drinking water scarcity in the southwestern coastal region of the country.
\end{abstract}

Keywords Community adaptation - Community perception $\cdot$ Safe drinking water $\cdot$ Southwestern Bangladesh · Water scarcity

Md. A. Abedin ( $\square) \cdot$ U. Habiba $\cdot$ R. Shaw

Graduate School of Global Environmental Studies, Kyoto University, Yoshida Honmachi, Sakyo-Ku, Kyoto 606-8501, Japan

e-mail: masumagriculture@yahoo.com

\section{Introduction}

Safe drinking water demand is increasing with the increase of population in the world. According to the United Nations, one third of the world's population lives in water shortage areas, of which about 1.1 billion people live without access to safe drinking water (Shaw and Thaitakoo 2010). The global consumption of water is doubling every 20 years, twice the rate of population growth and it is estimated that in 2025 at least 3 billion people will be living in areas where it will be difficult or even impossible to meet basic water needs (Concern Worldwide 2012). Water is crucial for all life on earth. It can improve the health, economy, food production, environment, and social well-being of a community. However, every year, millions of people use unsafe drinking water causing diarrhea, cholera, typhoid, and parasites (Curry 2010).

Water related problems are particularly acute in Asia. As population growth and urbanization rates in Asia rise rapidly, stress on the region's water resources is intensifying. Climate change deteriorates the situation significantly. Moreover, reduced access to freshwater will lead to a cascading set of consequences, including impaired food production, the loss of livelihood security, large-scale migration within and across borders, and increased economic and geopolitical tensions and instabilities.

In Bangladesh, there is an abundance of water, but scarcity of safe drinking water is the reality at present. Nearly one fourth of the population has no access to safe drinking water (WHO 2008). In the early 1990s, almost $97 \%$ of the rural population had no access to improved sources of drinking water. Both the surface water and groundwater are used for drinking purposes; however, groundwater is the most reliable source of drinking water. Currently, $73 \%$ of the rural population use tube well water 
as the primary source of drinking water (WHO and UNICEF 2010). Aside from increased population growth and rapid urbanization, inefficient water management in the region further exacerbates the safe drinking water situation. According to the Coastal Zone Policy 2005, 76 upazilas (subdistricts) of 19 coastal districts in Bangladesh are likely to be seriously affected by a rise in sea level. About 15 million people already are forced to drink saline water and 30 million people are unable to collect potable drinking water due to a lack of available safe water sources (Hoque 2009).

The southwestern coastal region is facing extreme difficulties in accessing safe drinking water (Quazi 2006). Arsenic contamination, groundwater depletion, flooding, drought, and salinity are major difficulties for the rural people to get safe drinking water from both surface and groundwater sources (Abedin et al. 2013). The development of a dependable water supply system in the coastal areas of Bangladesh is inadequate due to unavailability of freshwater aquifers at suitable depths (Kamruzzaman and Ahmed 2006; Islam et al. 2010). There are certain areas in the coastal districts where both shallow and deep tube wells are off use due to high salinity and natural arsenic in the groundwater. In general, people in this region use ponds known as mitha pukur with pond sand filters as safe drinking water sources. However, the water scarcity situation worsens during the dry season when recurrent droughts dry up ponds. This region has attracted the attention of environmentalists because of the presence of both world heritage sites and ecologically critical areas such as the Sundarbans, the world's largest mangrove ecosystem (Agrawala et al. 2003; MoWR 2006; Islam 2008). But these areas are lagging behind in socioeconomic development and are vulnerable to different disasters, environmental degradation, and global climate change. In addition to the impact on agriculture, with increasing climatic variability, salinization of water sources is becoming a major problem (Dankelman et al. 2008).

Over the years, the local people in the southwestern coastal areas of Bangladesh have adopted various water consumption practices according to varying levels of water availability. Ensuring access to safe drinking water is one of the most important issues for human health and sustainable socioeconomic development in these areas. Sustainable safe drinking water supply and access cannot be achieved without involving the local community in the planning and development processes. Although government agencies, local government institutions, other organizations and development partners are involved in water management in Bangladesh and the Department of Public Health and Engineering (DPHE) has the mandate to supply safe drinking water in both rural and urban areas, involvement and ownership by local communities are the key to any successful program, since communities respond first to any kind of natural disaster that happens in their locality. Moreover, community participation and control are essential for successful implementation, orientation, and maintenance of any disaster risk reduction project (Habiba and Shaw 2012). Therefore, overcoming the water problem should start with and be led by people in the local communities who are often the real experts on water issues. For this reason, it is important to find out community perception and existing adaptation and coping practices on drinking water scarcity.

This study provides a brief overview of safe drinking water scarcity occurring due to salinity, arsenic, and drought at the local level in southwestern Bangladesh. It examines the coastal communities' perception on water scarcity and their vulnerabilities and adaptation and coping measures. It further determines communities' expectations for government and nongovernment organizations to overcome the drinking water scarcity problem. The study aims to provide a realistic and novel aid for interventions by government and development organizations that deal with drinking water scarcity and enhance community preparedness against this problem in the future, and helps the government and policy makers to formulate a communitybased adaptability action plan at the local level.

\section{Study Area}

Khulna and Satkhira districts are located in the southwestern coastal region of Bangladesh with a population of 6.2 million (Abedin and Shaw 2013a). This area experiences severe drinking water scarcity due to salinity intrusion, arsenic, and drought (Fig. 1). In these two districts, two upazilas (subdistricts) have been categorized as experiencing severe and another two upazilas as undergoing moderate drinking water scarcity conditions. Categorization of severe and moderate safe drinking water scarcity upazilas is not based on quantitative criteria. Severe and moderate safe drinking water scarcity upazilas have been defined based on the local conditions that exist in each upazila. For instance, Rupsha and Debhata upazilas have lower scarcity because of the presence of appropriate national water quality standards; adequate training programs on water issues; the presence of safe drinking water sources such as ponds equipped with sand filters; rainwater harvesting systems; arsenic-free manually operated tube wells; strong coordination and collaboration among various stakeholders such as governmental organizations, NGOs, and community; satisfactory allocation in the water sector; and proper utilization of budget and knowledge-sharing activities. For example, the DPHE of Rupsha upazila is continuously working to screen arsenic contaminated tube 


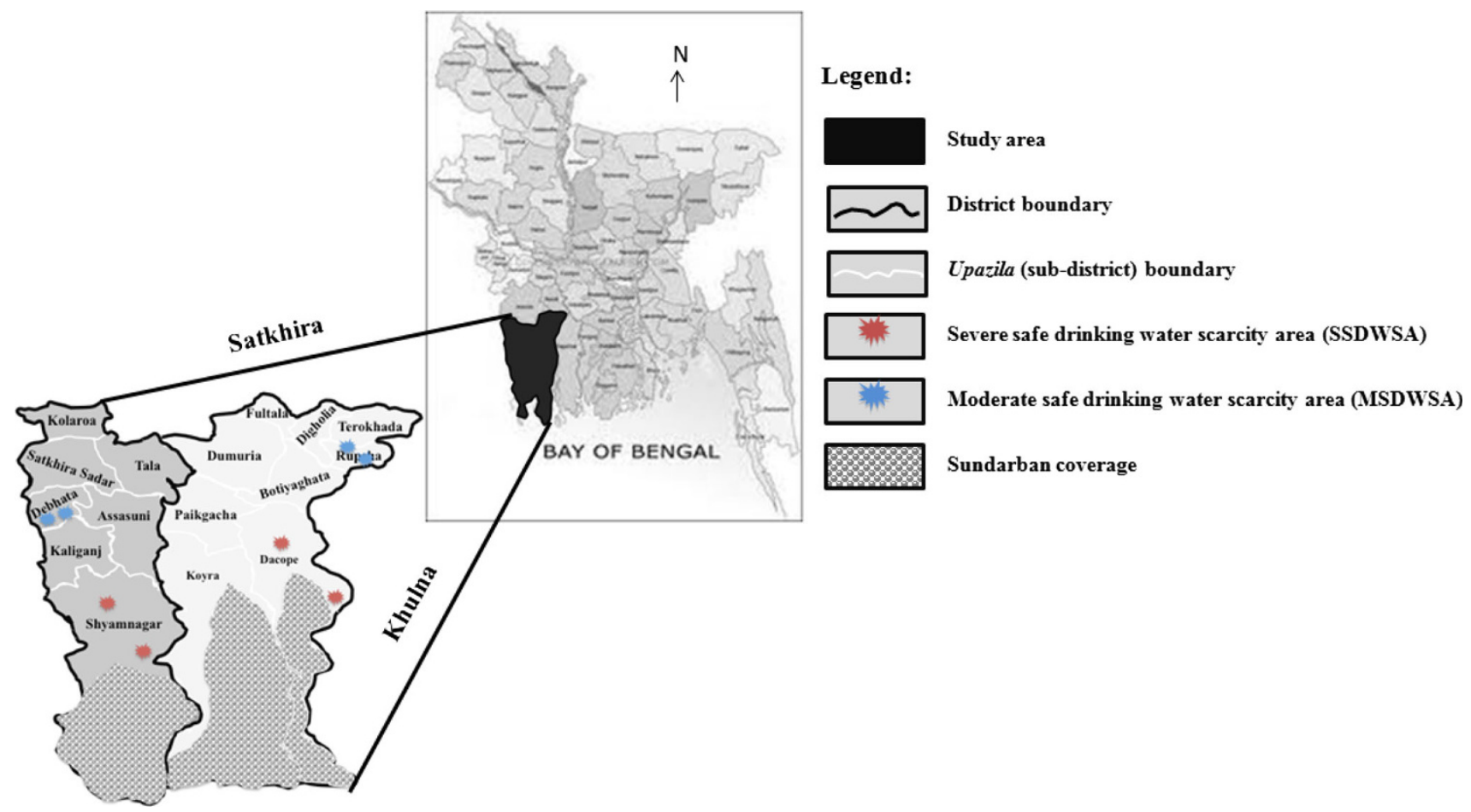

Fig. 1 Location of severe and moderate drinking water scarcity areas in Khulna and Satkhira districts of Bangladesh

wells to provide safe drinking water at the community level, whereas Debhata upazila establishes shallow and deep tube wells and constructs community-based arsenic and iron removal plants through institutions such as DPHE and a local company named Delta. On the other hand, Dacope and Shymnagar upazilas have severe potable water problems due to insufficient safe surface and groundwater sources, inadequate infrastructure, lack of budget resources, and poor salinity and arsenic policies at the upazila level (Abedin and Shaw 2013a).

Climatologically, the study area shows temperature and rainfall variations over the past few decades (Ahmed 2008; Miah 2010). The average maximum temperature is $33{ }^{\circ} \mathrm{C}$ during March to May while the average minimum temperature is about $15{ }^{\circ} \mathrm{C}$ in December and January (Chowdhury 2007; Ahmed 2008). Khulna and Satkhira districts receive an average rainfall of about $1,710 \mathrm{~mm}$ per annum, of which about $78 \%$ falls within the four monsoon months of July to October.

Salinity intrusion both in surface water and groundwater poses a great threat to access to safe drinking water by people in the study area. In this coastal area, a direct consequence of sea level rise would be intrusion of salinity with tide through rivers and estuaries. Salinity intrusion gradually accelerates with tidal flooding during the wet season; direct inundation by saline or brackish water; upward or lateral movement of salinity in groundwater during the dry season; and inundation by brackish water for shrimp farming (Habiba et al. 2013). The region is experiencing a decline in freshwater due to the reduction of existing freshwater ponds and pockets of safe groundwater aquifers as a result of saltwater from rivers being brought into wetland shrimp cultivation. This increases salinity of adjacent freshwater ponds and shallow aquifers through seepage that ultimately creates problems for drinking water safety. Moreover, salinity ingress has been observed as a consequence of reduced dry season flow of the major distributaries of the Ganges River, which started with the diversion of the Ganges flow by India following the construction of the Farakka barrage (Mirza 2004).

Arsenic is another factor that enhances drinking water scarcity in the region. Natural arsenic is found in underground water. A local NGO in the southwestern region has reported that $79 \%$ of the tested tube wells of shallow aquifers are contaminated with arsenic that is beyond the acceptable limit-Government of Bangladesh (GoB) recommends the arsenic drinking water standard of $50 \mu \mathrm{g} 1^{-1}$ (Farhana 2011). The presence of arsenic in groundwater has aggravated the scarcity of safe drinking water in the region. Moreover, it is notable that arsenic is distributed in a discontinuous, patchy mosaic in the study region. The arsenic level of one tube well in a particular household may be above the acceptable limit, but $20-50 \mathrm{~m}$ away the arsenic level of another household's tube well may be below the acceptable limit. 
Table 1 Method of the study in Bangladesh

\begin{tabular}{clccl}
\hline Time period & $\begin{array}{l}\text { Number of } \\
\text { samples }\end{array}$ & Purpose of data collection & $\begin{array}{l}\text { Method of data } \\
\text { collection }\end{array}$ & Target group \\
\hline $\begin{array}{c}\text { 9 October-1 } \\
\text { November, } \\
2012\end{array}$ & $\begin{array}{c}240 \text { (30 } \\
\text { questionnaires } \\
\text { from each } \\
\text { village) }\end{array}$ & $\begin{array}{c}\text { To assess the impact of water } \\
\text { scarcity on livelihood and } \\
\text { identify local coping strategies }\end{array}$ & $\begin{array}{c}\text { Questionnaire } \\
\text { survey through } \\
\text { random } \\
\text { sampling }\end{array}$ & Household head \\
$\begin{array}{cccc}\text { October-1 } \\
\text { focus groups } \\
\text { (one from each } \\
\text { village) }\end{array}$ & $\begin{array}{c}\text { To cross-check and validate data } \\
\text { obtained from household } \\
\text { questionnaire survey }\end{array}$ & $\begin{array}{c}\text { Focus group } \\
\text { discussion }\end{array}$ & $\begin{array}{c}\text { Each group consisted of teachers, local community } \\
\text { leaders, NGO staff, elected members of } \text { Upazila } \\
\text { parisad }\end{array}$ \\
journalists
\end{tabular}

${ }^{1}$ Upazila parisad is a national institute of local government governed by the Ministry of Local Government, Rural Development and Cooperatives, Government of People's Republic of Bangladesh

Apart from salinity and arsenic, drought has dire impacts on drinking water access and supply in the study area during the dry season (Abedin et al. 2012). Presently, the sources of freshwater in the southwestern coastal region are the Garai and Madhumati Rivers (Swapan and Mamun 2006). The freshwater flow of these rivers decreases during prolonged dry spells, increases the level of salinity and eventually worsens drinking water scarcity in the region. In addition, a large number of people depends on freshwater ponds for drinking purposes, which dry up due to drought. Drought also intensifies the decline of the water table, which leads to reduced water availability in many tube wells (Swapan and Mamun 2006).

\section{Research Design}

The severity and extent of the problem of saline-degraded drinking water are explored through a literature review and preliminary field investigation. The goal is to assess local people's perception and awareness of the problem, analyze the reasons for and impacts of drinking water scarcity, and identify the adaptations and coping practices of local communities. The methodological structure of the study is outlined in Table 1.

In order to fulfill the objectives, a semistructured questionnaire (Q) was developed and designed in three parts. In the first part, the questions were formulated to gather information about a respondent's socioeconomic characteristics and in the second part, the questions highlight their perception and awareness on drinking water scarcity. In the last part, the questions look into the impact of drinking water scarcity on a respondent's livelihood and various adaptation practices and coping strategies towards salinity intrusion, arsenic, and drought. The questionnaire survey was conducted by the first author with the assistance of trained university students in eight villages of four upazilas (in both severe and moderate drinking water scarcity areas) in two districts of southwestern coastal Bangladesh during
October 2012. Figure 2 shows the sampling structure of the study. A total of 240 questionnaires were randomly distributed and collected at these villages (30 questionnaires from each village; 120 questionnaires from upazilas with a severe drinking water problem and 120 from those experiencing moderate scarcity). Focus group discussion was carried out to cross-check and validate the answers from respondents.

\section{Community Perception and Adaptation and Coping Measures for Drinking Water Scarcity}

Since communities are at the forefront in responding to hazardous conditions, their perception is important. This section describes the respondents' socioeconomic characteristics followed by their perception on drinking water scarcity. The focus then shifts to the impacts of this scarcity in their locality. After understanding and summarizing community perception, adaptation, and coping measures at both individual and community levels, coping strategies supported by institutions are identified and communities' expectations for government and nongovernment organizations are revealed.

\subsection{Socioeconomic Characteristics}

Respondents' socioeconomic characteristics such as gender, age, education, occupation, and income level affect how they perceive the effect of drinking water scarcity on their life and livelihood. Socioeconomic conditions also contribute to increasing or reducing vulnerability and enabling or preventing individuals to take certain adaptive measures during crisis periods. Data in Table 2 highlight that the majority of the respondents in both severe and moderate drinking water scarcity areas are male (64 and $72 \%$, respectively) as most of the households are male dominated. Age of most of the respondents in both severe and moderate scarcity areas lies between 25 and 59 years. 
Fig. 2 Sampling structure of the study in Bangladesh

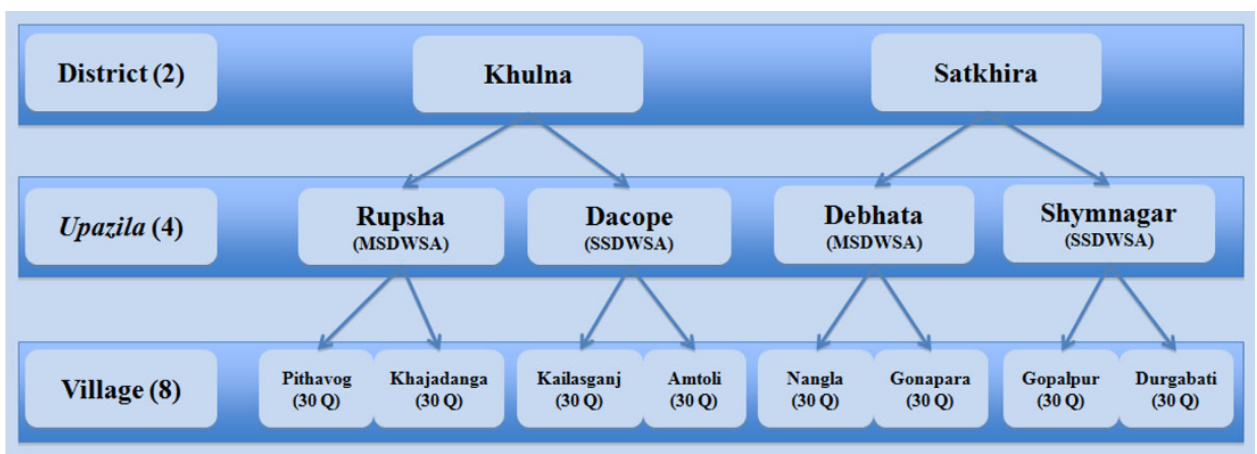

Table 2 Socioeconomic profile of respondents in Khulna and Satkhira districts of Bangladesh

\begin{tabular}{|c|c|c|}
\hline $\begin{array}{l}\text { Socioeconomic } \\
\text { parameter }\end{array}$ & $\begin{array}{l}\% \text { of respondents } \\
\text { in severe drinking } \\
\text { water scarcity } \\
\text { areas }\end{array}$ & $\begin{array}{l}\% \text { of respondents } \\
\text { in moderate drinking } \\
\text { water scarcity areas }\end{array}$ \\
\hline
\end{tabular}

\section{Gender}

Male

Female

64

72

Age group

Young (below

24 years)

Middle (25-44 years) $41 \quad 46$

Old (45-59 years) $\quad 48 \quad 50$

Aged (above 60 years) 8

Education

Illiterate

Primary school

Secondary school

College

Graduate

Religion

Islam

Hindu

Buddhist

Christian

Occupation

$\begin{array}{lll}\text { Agriculture } & 27 & 28 \\ \text { Services } & 15 & 13 \\ \text { Business } & 13 & 28 \\ \text { Labor } & 27 & 18 \\ \text { Other } & 18 & 13\end{array}$

Annual income level (Taka) (78.06 Tk $=1 \$$ as of 27 June 2013)

$\begin{array}{llr}\text { Below 30,000 Tk } & 10 & 8 \\ 31,000-45,000 \mathrm{Tk} & 25 & 12 \\ 46,000-60,000 \mathrm{Tk} & 28 & 20 \\ 61,000-80,000 \mathrm{Tk} & 15 & 20 \\ \text { Above } 80,000 \mathrm{Tk} & 22 & 40\end{array}$

Middle- to old-aged persons are likely to have experienced drinking water scarcity at first hand, since this problem has been prominent in the region for three decades.

Most of the respondents are Muslim, followed by Hindu in the moderate drinking water scarcity areas, whereas more than half of the respondents in the severe scarcity areas are Hindu. More than $50 \%$ of the respondents have completed primary to secondary school education. A few respondents have completed college and graduate degrees. Less than $30 \%$ of the respondents are illiterate.

More than a quarter of the respondents in severe drinking water scarcity areas are engaged in agricultural activities as daily labor. In moderate scarcity areas, $28 \%$ of the respondents are in both the agriculture and business sectors. Near two-thirds of the respondents in severe drinking water scarcity areas have annual incomes lower than 60,000 Tk (769 USD), which is below the poverty line. Respondents have higher monthly incomes in moderate scarcity areas. Not only illiteracy but also low income makes respondents more vulnerable to safe drinking-water issue in severe as compared to moderate water scarcity areas.

\subsection{Perception}

The coastal area of Bangladesh is composed of different geomorphological regions with dissimilar hydrology, climate, and soils (Islam 2004). The area experiences all types of hazards including cyclones, tidal surges, floods, droughts, salinity intrusion, waterlogging, and land subsidence (Abedin et al. 2012). With increasing climate variability, Dankelman et al. (2008) note that salinization of drinking water sources is becoming a major problem. Ahmed (2008) argues that sea level rise further aggravates salinity ingress along coastal rivers. Salinity has increased the vulnerability of the people to the decreasing availability of potable water over the last few decades in the study area. Considering all the issues, the respondents were asked about the most prevalent hazards that directly related to 
reliable available drinking water in their locality. The survey results show that $96 \%$ of respondents from severe and $92 \%$ from moderate drinking water scarcity areas perceive salinity to be the most prevalent hazard that causes a lack of safe drinking water in these areas (Fig. 3). Apart from salinity, more than half of the respondents mentioned that arsenic and drought are also responsible for enhancing drinking water scarcity in this region.

The respondents were further asked about the natural and human causes of these hazards and the drinking water scarcity experienced in this region. Figure 4 shows that 90 and $96 \%$ of the respondents in severe and moderate drinking water scarcity areas respectively pointed out that the increase in salinity intrusion is the main natural cause that limits potable drinking water. In addition, 77 and $66 \%$

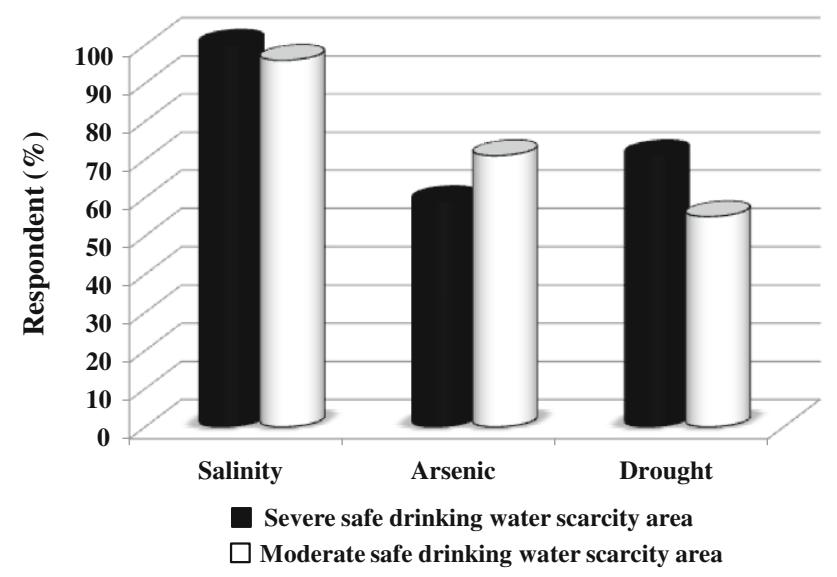

Fig. 3 Hazards related to safe water scarcity in Khulna and Satkhira districts of Bangladesh of the respondents stated that extensive shrimp cultivation is a human activity that compromises drinking water availability. The construction of Farakka Barrage, a direct human intervention, also was implicated in salinity and drinking water supply problems in the study area. Islam and Gnauck (2008) report that the establishment of Farakka Barrage over the Ganges River is one of the main reasons for salinity intrusion in the southwestern part of Bangladesh.

Besides salinity, 35 and $28 \%$ of respondents in severe and moderate drinking water scarcity areas indicated that arsenic rich minerals in the groundwater aquifer is the main natural reason for decreased drinking water resources in the area (Fig. 4). The respondents who identified this cause are the well educated-only the educated people in the area have this knowledge.

With regard to human causes, $61 \%$ of respondents from moderate drinking water scarcity areas claimed that excessive use of groundwater is the prime reason for arsenic contamination in the region. The release of arsenic in groundwater occurs through the oxidation of sulfide minerals and the reduction of oxihydroxide under reducing conditions (Horneman et al. 2004; Appelo 2006; Abedin and Shaw 2013b). Human activities that significantly influence sulfide mineral oxidation and arsenic release into the aquifer are the increased pumping of groundwater. Increased pumping and reduced recharge can greatly accelerate oxidation rates of arsenic-bearing minerals by lowering the water table and exposing minerals to atmospheric oxygen.

Aside from salinity and arsenic, more than half of the respondents in both severely and moderately impacted

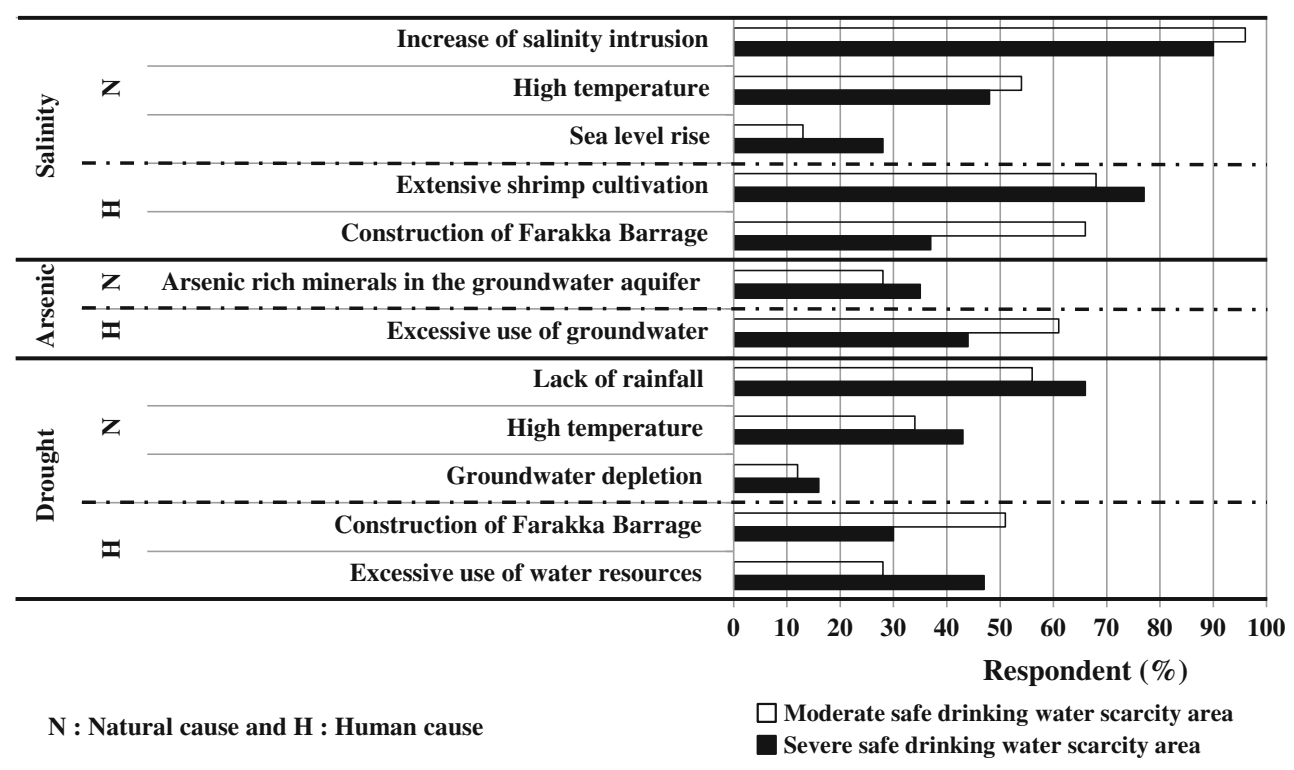

Fig. 4 Natural and human causes for increasing drinking water scarcity in Khulna and Sutkhira districts of Bangladesh 
areas highlighted drought as the main natural cause of insufficient safe drinking water (Fig. 4). Among human causes, $52 \%$ of the respondents in moderate drinking water scarcity areas cited construction of the Farakka Barrage as responsible for increasing drinking water scarcity whereas $47 \%$ of the respondents in severe scarcity areas identified the excessive use of water resources for irrigation purposes through installed deep tube wells (Fig. 4).

\subsection{Impacts}

Poor socioeconomic conditions, along with salinity, arsenic, and drought, are the principal reasons for increasing drinking water scarcity in the study area. Table 3 reveals that lack of safe drinking water has serious impacts on the daily life, livelihood, and environment of the local population.

More than 5 million people in the southwestern part of Bangladesh have been suffering from a safe drinking water crisis (Swapan and Mamun 2006). The common sources of drinking water are the limited number of ponds with sand filters, rainwater harvesting systems, and arsenic-free hand operated tube wells. Due to the lack of safe drinking water sources, most people in the study area consume large quantities of saline and arsenic contaminated water. Table 3 reveals that $100 \%$ of the respondents in both severe and moderate scarcity areas stated that water scarcity has substantial impacts on their daily activities through disturbances to domestic work, health problems, social conflicts, and hardship for women as women walk from one village to another to fetch water (Fig. 5). In extreme cases, women in some villages walk $6-12 \mathrm{~km}$ in order to fulfill the daily requirement of 3 jars of water per household. Various social crises such as the hampering of children's education and the harassment of women when they are fetching water arise from this problem.

The scarcity of safe drinking water impacts many aspects of the daily life of respondents, but none more important than those that have emerged in livelihood and the environment. Since the 1980s, vast lands have been brought under rice cultivation; many of these areas in addition to other agriculture-based livelihoods have experienced difficulties due to increased salinity stemming in part from the expansion of seawater shrimp cultivation.

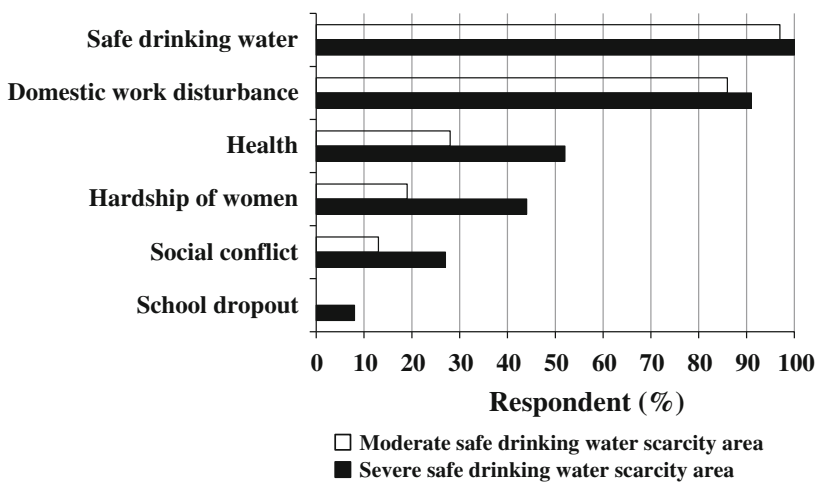

Fig. 5 Impacts of drinking water scarcity on daily life in Khulna and Satkhira districts of Bangladesh

There is growing documentation on the adverse effects of high salinity levels on rice-high soil salinity prevents growth (Tho et al. 2008), reduces germination, causes browning of rice fields (Gain 1995), and decreases rice production (Ali 2006). Table 3 shows that $72 \%$ of respondents in severe and $82 \%$ of respondents in moderate safe water scarcity areas have been affected in their agriculture-based livelihood because of soil and water salinity. Fisheries and livestock-based livelihoods are also curtailed due to the region's lack of safe water. Unavailability of safe water not only decreases fish production but also causes deterioration of milk productivity and reproductive health of livestock. That ultimately hampers livelihood. In total, 54 and $64 \%$ of respondents in both areas indicated that environmental degradation has occurred due to lack of safe water. Reduction in the number of species of medicinal plants and trees, disappearance of indigenous species of fish, reduction in soil fertility, and loss of biodiversity in the Sundarban forest (Gopal and Chauhan 2006) have emerged due to the lack of fresh water. Swapan and Mamun (2006) found similar types of results in their study regarding impacts on the environment due to safe water scarcity.

People in the study area suffer from various healthrelated problems caused by saline, impure, or arsenic contaminated water. According to the Food and Agriculture Organization's recommendation, consumption of salt should be limited within $5 \mathrm{~g}$ day $^{-1}$, but people in the study area take up to $16 \mathrm{~g}$ of salt just by drinking the water (Daily

Table 3 Overall impacts of safe water scarcity in Khulna and Satkhira districts of Bangladesh

\begin{tabular}{|c|c|c|c|c|c|}
\hline \multirow[t]{2}{*}{ Category } & \multirow[t]{2}{*}{ Daily life } & \multicolumn{3}{|l|}{ Livelihood } & \multirow[t]{2}{*}{ Environment } \\
\hline & & Agriculture & Fisheries & Livestock & \\
\hline Respondent in severe drinking water scarcity area $(\%)$ & 100 & 72 & 20 & 45 & 54 \\
\hline Respondent in moderate drinking water scarcity area $(\%)$ & 100 & 82 & 7 & 24 & 64 \\
\hline
\end{tabular}




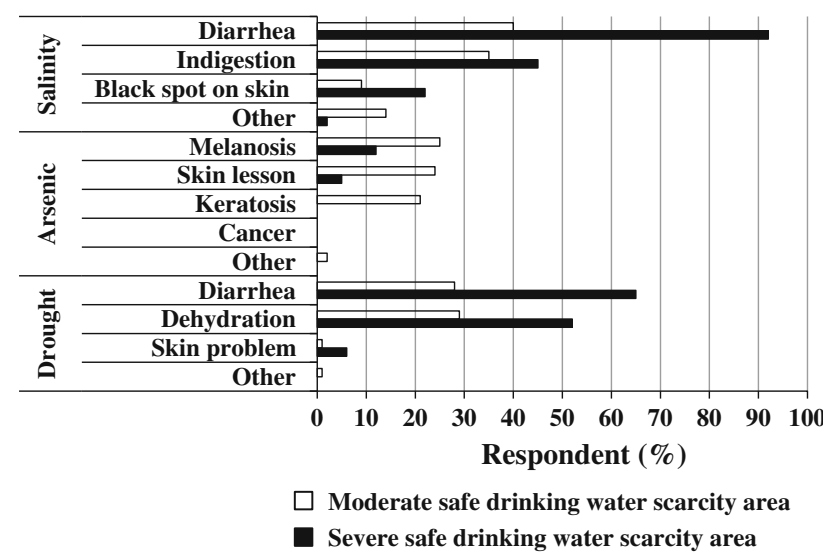

Fig. 6 Impacts of drinking water scarcity on health in Khulna and Satkhira districts of Bangladesh

Star 2013). As a consequence, various skin and intestinal diseases, dysentery, fever, and diarrhea become a regular part of life for the people in salinity affected areas (Swapan and Mamun 2006; Abedin et al. 2012). Women in the study area suffer from a gynecological disorder (lowering of the uterus) caused by carrying big jars of water on their hip when fetching drinking water from a long distance. Data in Fig. 6 highlights that 92 and $40 \%$ of respondents in the severe and moderate scarcity areas respectively, often suffer from diarrhea, especially infants and children, due to the consumption of saline water. They also suffer from indigestion, black spots on the skin and so on.

Arsenic contaminated drinking water causes melanosis, ketatosis, skin lesions, and even death (Hadi and Parveen 2004; Borghesi and Vercelli 2005; Abedin et al. 2012; Abedin and Shaw 2013c). Our survey results show that the severity of arsenic contamination is higher in moderate drinking water scarcity areas than in severe scarcity areas (Fig. 6). This is due to the geographical distribution of arsenic and the high percentage of water supply through tube wells in the moderate scarcity areas. Apart from salinity and arsenic, more than $50 \%$ of respondents in severe drinking water scarcity area face intestinal problems such as diarrhea and dehydration. Young girls have difficulty getting married due to skin problems and the divorce rate is increasing.

\subsection{Adaptation and Coping Measures}

Adapting to or coping with water scarcity means to live in harmony with the environmental conditions specific to and dictated by limited available water resources (Pereira et al. 2009). Adaptation is a two way process, which initially requires the recognition of changes and then responding to change through adaptation (Habiba et al. 2012). For millennia, civilizations have developed in water scarce environments and have cultural skills that make it possible to live under such conditions. To reduce the safe drinking water scarcity problem, different stakeholders adopted various approaches. The specific adaptation and coping actions of individuals, local communities, and institutions (local governments, NGOs, and private sector) are all important because together they can potentially reduce the safe water scarcity in a locality. This section introduces adaptation and coping measures adopted at the individual and community levels in the southwestern region of Bangladesh as well as those supported by various organizations based outside local communities.

\subsubsection{Individual and Community Level}

Survey results in Table 4 display the existing adaptation and coping measures that are followed by individuals as well as communities to combat drinking water scarcity. At the individual level, depending on socioeconomic conditions, a respondent employs measures that are manageable for a single household, whereas at the community level, members of a community share responsibilities and draw benefits from the measures they adopt collectively. For example, small units of ponds with sand filters and rainwater harvesting systems are considered as the most suitable safe drinking water options used by individual households. Large ponds with sand filters and large rainwater harvesting systems are used in communities and are now the only major sources of safe drinking water maintained at the community level (Habiba et al. 2013). Very few people have the ability to buy purified water from water treatment plants or shops; the majority of residents cannot afford such expenses.

Table 4 shows that to combat drinking water scarcity caused by salinity, the respondents from both the severe and moderate drinking water scarcity areas (62 and $31 \%$, respectively) adopted the measure of conserving pond water as the most effective adaptation and coping measure at the individual levels. In addition, 42 and $48 \%$ respondents in these areas collected safe water from far distance 3-5 km. Figure $7 \mathrm{a}, \mathrm{b}$ show how people conserve and use pond water for drinking purposes. Likewise, $45 \%$ respondents in areas experiencing severe drinking water deficits have adopted rainwater harvesting as another suitable option by which to cope with a lack of drinking water at the individual level. They argued that the rainwater harvesting equipment is their own property; hence they can use the preserved water whenever they want. Farhana (2011) found a similar result where people in the coastal belt of Bangladesh used rainwater for a long time as a source of drinking water. Figure 8 shows the various rainwater systems in severe drinking water scarcity areas that people are now using. 
Table 4 Adaptation and coping measures at different levels in Khulna and Satkhira districts of Bangladesh

\begin{tabular}{|c|c|c|c|}
\hline & Adaptation and coping practice & $\begin{array}{l}\text { Respondent in } \\
\text { severe drinking } \\
\text { water scarcity } \\
\text { area }(\%)\end{array}$ & $\begin{array}{l}\text { Respondent in } \\
\text { moderate drinking } \\
\text { water scarcity } \\
\text { area }(\%)\end{array}$ \\
\hline \multicolumn{4}{|c|}{ Individual level } \\
\hline \multirow[t]{2}{*}{ Salinity } & Rainwater harvesting & 45 & 3 \\
\hline & Conservation of pond water & 62 & 31 \\
\hline \multirow[t]{4}{*}{ Arsenic } & Boiled pond water & 12 & 13 \\
\hline & Use of pond sand filter & 10 & 16 \\
\hline & Collecting water from far distance $(3-5) \mathrm{km}$ & 42 & 48 \\
\hline & Installing deep tube well & 1 & 5 \\
\hline \multirow[t]{2}{*}{ Drought } & Digging of pond & 4 & 1 \\
\hline & Other & 6 & 0 \\
\hline \multicolumn{4}{|c|}{ Community level } \\
\hline \multirow[t]{4}{*}{ Salinity } & Conservation of pond water & 28 & 5 \\
\hline & Rainwater harvesting & 13 & 0 \\
\hline & Use of pond sand filter & 19 & 33 \\
\hline & Digging of pond & 23 & 5 \\
\hline \multirow[t]{2}{*}{ Arsenic } & Use of pond sand filter & 5 & 15 \\
\hline & Digging of pond & 11 & 2 \\
\hline Drought & Formation of different water committees & 2 & 3 \\
\hline \multicolumn{4}{|c|}{ Institutional level } \\
\hline \multirow[t]{4}{*}{ Salinity } & Rainwater harvesting system & 35 & 0 \\
\hline & Installing deep tube well & 3 & 13 \\
\hline & Pond sand filter & 30 & 36 \\
\hline & Installation of deep tube well with overhead tank & 8 & 18 \\
\hline \multirow[t]{3}{*}{ Arsenic } & Pond sand filter & 10 & 5 \\
\hline & Installing deep tube well & 3 & 8 \\
\hline & Screening of tube well for contamination & 12 & 40 \\
\hline Drought & Reexcavation of pond & 8 & 0 \\
\hline
\end{tabular}

Fig. 7 Conservation and use of pond water for drinking in southwestern Bangladesh. a Conservation of pond water. The sign reads "Washing hands and legs and ablution are strictly forbidden (Ordered by the authority)", b collection of pond water

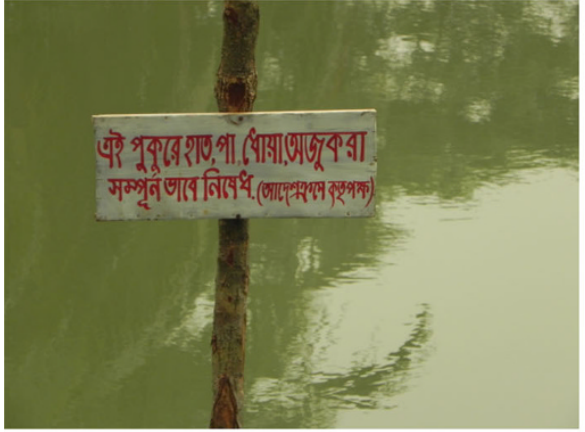

(a) Conservation of pond water. The sign reads "Washing hands and legs and ablution are strictly forbidden (Ordered by the authority)"

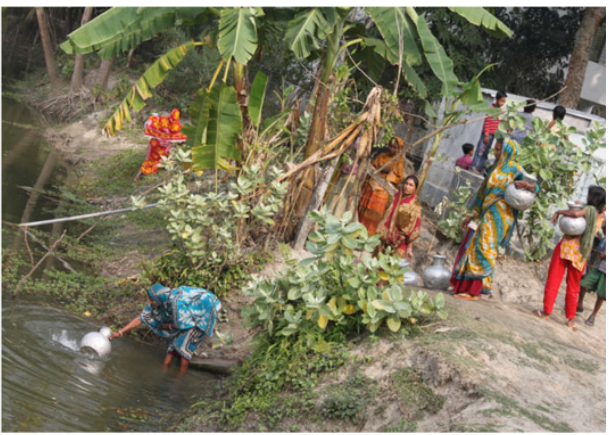

(b) Collection of pond water
At the community level, use of pond sand filtration is the most common practice in moderate water deficit areas. Pond sand filters are promoted by the government, international NGOs, and local NGOs to provide a safe drinking water supply with the cooperation of a community's people. Table 4 shows that 19 and $5 \%$ respondents 
Fig. 8 Different rainwater harvesting systems in southwestern Bangladesh. a Concrete container, $\mathbf{b}$ earthern container, c plastic container

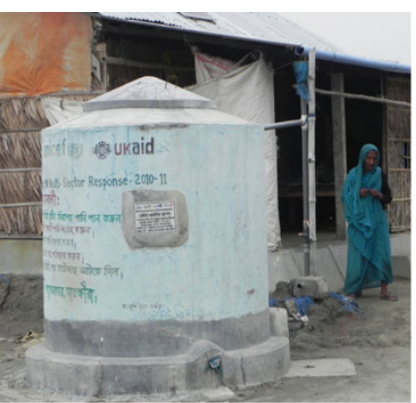

(a) Concrete container

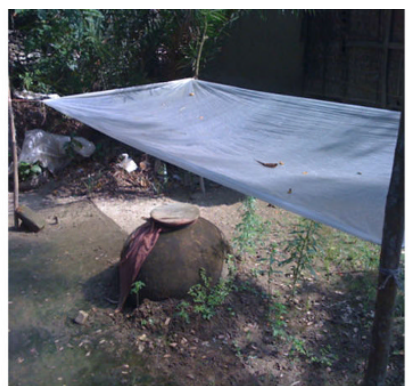

(b) Earthern container

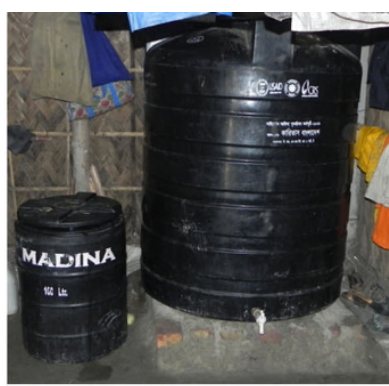

(c) Plastic container
Fig. 9 Technology for safe drinking water in southwestern Bangladesh. a Pond sand filter, b deep tube well with overhead tank

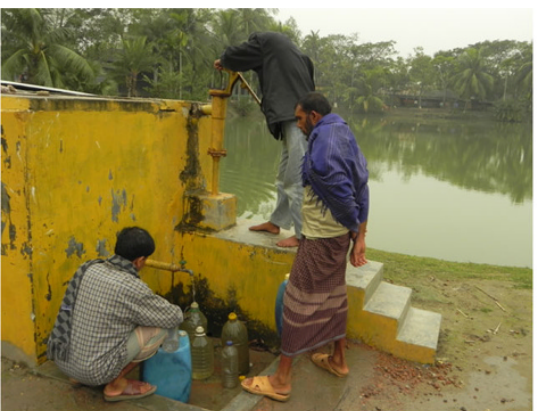

(a) Pond sand filter

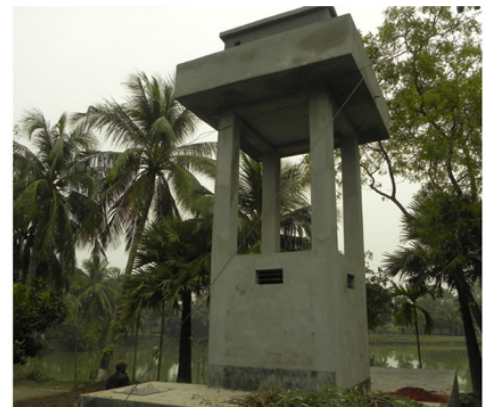

(b) Deep tube well with overhead tank from severe drinking water scarcity areas use pond sand filters respectively to get safe drinking water with minimal salinity and arsenic contamination, whereas 33 and $15 \%$ of the respondents from moderate drinking water scarcity areas utilized the same practice.

\subsubsection{Institutional Level}

Institutions play a leading role in supplying drinking water in the whole country. Various local and international NGOs such as Sushilan, Uttaran, ActionAid, Caritas, Concern Worldwide, UNICEF (United Nations Children's Fund), USAID (United States Agency for International Development), and government organizations such as DPHE (Department of Public Health) and CDMP (Comprehensive Disaster Management Program) are involved in supplying drinking water in coastal Bangladesh. Among them, UNICEF and DPHE carried out the introduction of pond sand filters (PSF) along the coastal belt. The respondents in the study area were asked about the types of adaptation and coping measures supported and implemented by different institutions. Considering the salinity problem, the survey results in Table 4 shows that 36 and $30 \%$ of the respondents in moderate and severe drinking water scarcity areas adopted PSFs to get safe drinking water, with the assistance of government organizations (for example DPHE) and nongovernment organizations (like Sushilan) in co- operation with donor agencies as well as international NGOs (for example Caritas and UNICEF) (Fig. 9a). In addition, $35 \%$ of the respondents from severe drinking water scarcity areas practice rainwater harvesting technology by conserving rainwater during the rainy season and using it for drinking purposes with the help of various NGOs. Besides the pond sand filter and rainwater harvesting technology, 8 and $18 \%$ of respondents from severe and moderate scarcity areas respectively use deep tube wells with overhead tanks installed by the local NGO Iswaripur Development Foundation (IDF), with GIZ (German Development Cooperation) assistance (Fig. 9b).

At the institutional level, screening and identifying of arsenic contamination from hand-operated tube wells is the first step in arsenic mitigation (Abedin et al. 2012). The DPHE, assisted by UNICEF, carried out the screening of arsenic contaminated hand-operated tube wells from 2000 to 2006 in the country as the topmost coping measure to eliminate arsenic from Bangladesh's drinking water. Once a tube well is determined to have a higher concentration of arsenic than the national standard, the tube well is marked with red paint in contrast with tube wells that are safe to drink, which are marked with green paint (Fig. 10a, b). Forty percent of the respondent from moderate drinking water scarcity areas have benefited from the initiative, whereas only $12 \%$ of the respondents from severe water scarcity areas reported the same positive result. 
Fig. 10 Screening of tube wells in southwestern Bangladesh. a red marked tube well unfit for drinking, b green marked tube well fit for drinking

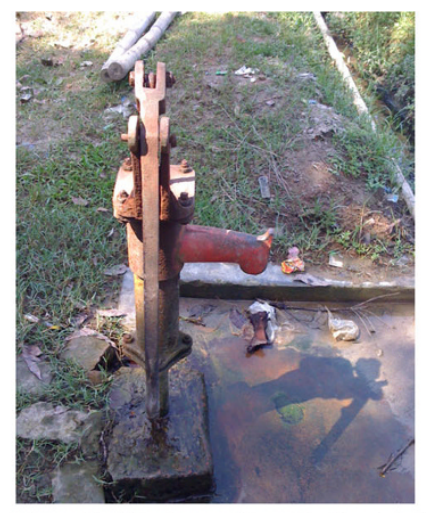

(a) Red marked tube well unfit for drinking

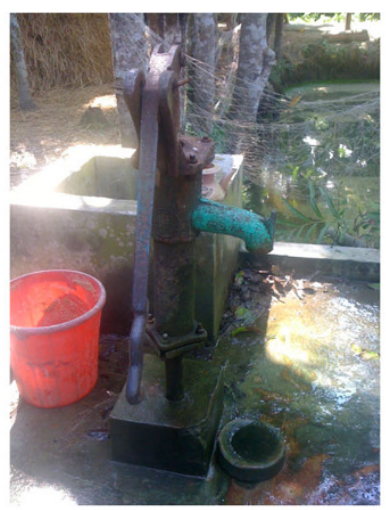

(b) Green marked tube well fit for drinking
Fig. 11 Need for support from government and nongovernment organizations in southwestern Bangladesh

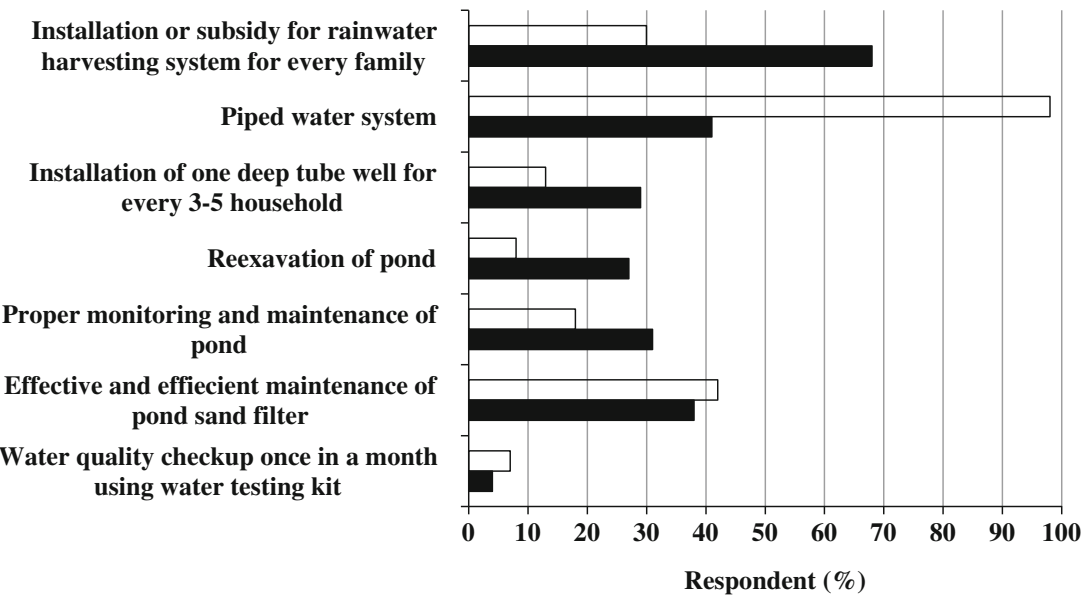

$\square$ Moderate safe drinking water scarcity area

Severe safe drinking water scarcity area
Considering drought, reexcavation of ponds is the only coping measure in severe drinking water scarcity areas. However, the number and coverage of these efforts are very limited according to the respondents.

\subsection{Expectations for Institutional Support to Enhance Community Adaptability and Coping Capacity}

Despite a number of adaptation and coping measures that have been implemented in the study area to upgrade drinking water quality and supply, given the magnitude of the problem, the current efforts of individuals and communities are still insufficient. Most of these measures are reactive rather than proactive, autonomous instead of well planned. This study has tried to identify methods that can help these communities and institutions deal with salinity, arsenic, and drought conditions that diminish safe drinking water capacity.

Respondents in the study area were asked about their expectations for support from the government or NGOs to reduce their vulnerability to drinking water scarcity. Survey results indicate that $68 \%$ of respondents in severe drinking water scarcity areas mentioned installation of or subsidy for rainwater harvesting for every family, whereas $98 \%$ respondents in moderate drinking water scarcity areas cited piped water systems as the topmost need for support (Fig. 11).

Apart from the questionnaire survey, this study also conducted focus group discussions (FGDs) to get an understanding of probable solutions the communities consider viable to solve the drinking water problem and their communities' needs. Based on the FGD, a few recommendations are summarized below:

- Installation of rainwater harvesting systems at the family level. The government should take proper initiatives in consultation with community members and local NGOs to make the projects sustainable.

- Installation of rainwater harvesting systems in all government and nongovernment organization offices, schools, and colleges. The government should include 
this activity during policy formulation at both national and local levels with the bilateral agreement of the Union Parishad and International and national NGOs.

- Installation of solar-powered deep tube wells with overhead tanks that supply piped water to homes and shared community outlets, since piped water supply is the topmost desired option at communities in moderate drinking water scarcity areas. A good example is the project of the Iswaripur Development Foundation, with the financial assistance from the German Development Cooperation, which is developing a solar-powered deep tube well system with overhead storage tank. Strong cooperation among different stakeholders, government, NGOs, and donor agencies, can facilitate the achievement of safe drinking water adaptation initiatives and promote an effective safe drinking water adaptation policy.

- Community-based pond sand filters with proper governmental monitoring and maintenance. Pond sand filters are a simple, easy to use, and effective technique in the southwestern region of Bangladesh, but the innovation needs proper maintenance to run yearround. Community involvement is important to carry out the program successfully in close association with the government.

- Reexcavation of ponds with strict rules for use, as salinity, arsenic and drought prone areas of the country require a program of water conservation. As large dams are difficult to construct due to high cost, reexcavation of a number of small ponds may provide the same benefit as a large reservoir.

\section{Discussion and Conclusion}

The current level of adaptation and coping measures of the respondents remain inadequate to cope with the future challenges of safe drinking water supply. Most of these measures implemented in the study area are reactive rather than proactive, autonomous rather than well planned when adaptation and coping measures can take many forms and can be adopted at the level of national government, local government, and NGOs. In the past, the development activities mainly operated through various levels following top-down approaches and have become "supply-driven" in many countries. Recent developments in decentralization advocate a "demand-driven" strategy and have the merit of considering the specific demands and potential of each locality. According to Wijayaratna (2004), local government institutions and local community organizations could establish a collaborative partnership in undertaking the responsibility for developing a local "vision" and strategy; and designing/planning, allocating resources, implementing and monitoring/evaluating of development activities that would better cater to local needs. They would "jointly" become the driving force towards development, develop a "sense of shared ownership," and become "managers" of their development initiatives. Marfai et al. (2008) highlight that the development of effective hazardreduction programs requires cooperation and exchange of experiences of the hazard affected community and local government. Understanding the community's unique perception and assessing their adaptive and proactive capacities is important for creating successful coastal hazard management programs. This study has examined communities' perception of and adopted and expected coping measures for overcoming safe drinking water scarcity problems.

In the study area, salinity is the most prominent cause of accelerated safe drinking water scarcity, along with arsenic contamination and drought. In terms of arsenic contamination, DPHE has screened out the hand-operated tube wells contaminated with arsenic in the study area and prohibited the use of water from these sources for drinking. In contrast, the problem of salinity that poses a threat to drinking water sources has not been dealt with as effectively. Currently about 40 million people are directly affected by water and soil salinity and another 20 million are at risk in coastal Bangladesh. The increasing concentration of salinity will put more pressure on people's health and threaten livelihood, income generation, and food security of coastal populations. Although measures, including rainwater harvesting, conservation of pond water, local technology for water treatment (such as pond sand filters), and groundwater use management, have been implemented at the local and community levels and supported by various institutions to improve water supply, the salinity issue so far has not been a priority in the government's disaster management policy. Since the 1980s, salinity problems have received very little attention in Bangladesh; even the Coastal Zone Policy 2005 (Ministry of Water Resources 2005) developed by the government did not take salinity issues into account. The National Adaptation Program of Action (Ministry of Environment and Forest 2005) briefly explains the causes and impacts of water salinity on the coastal economy, whereas much more emphasis was placed on climate change and sea-level rise. More attention by government as well as by national and international NGOs is needed to overcome the salinity problem in the future.

Based on the results, Fig. 12 proposes a model for an integrated community-based approach to reducing drinking water scarcity. To mobilize these processes not only requires active participation of communities, but also needs feedback and support from various stakeholders such as governmental agencies, NGOs, and other organizations. It 
Fig. 12 Model for an integrated community-based approach to reducing safe drinking water scarcity in southwestern Bangladesh. Source: The authors

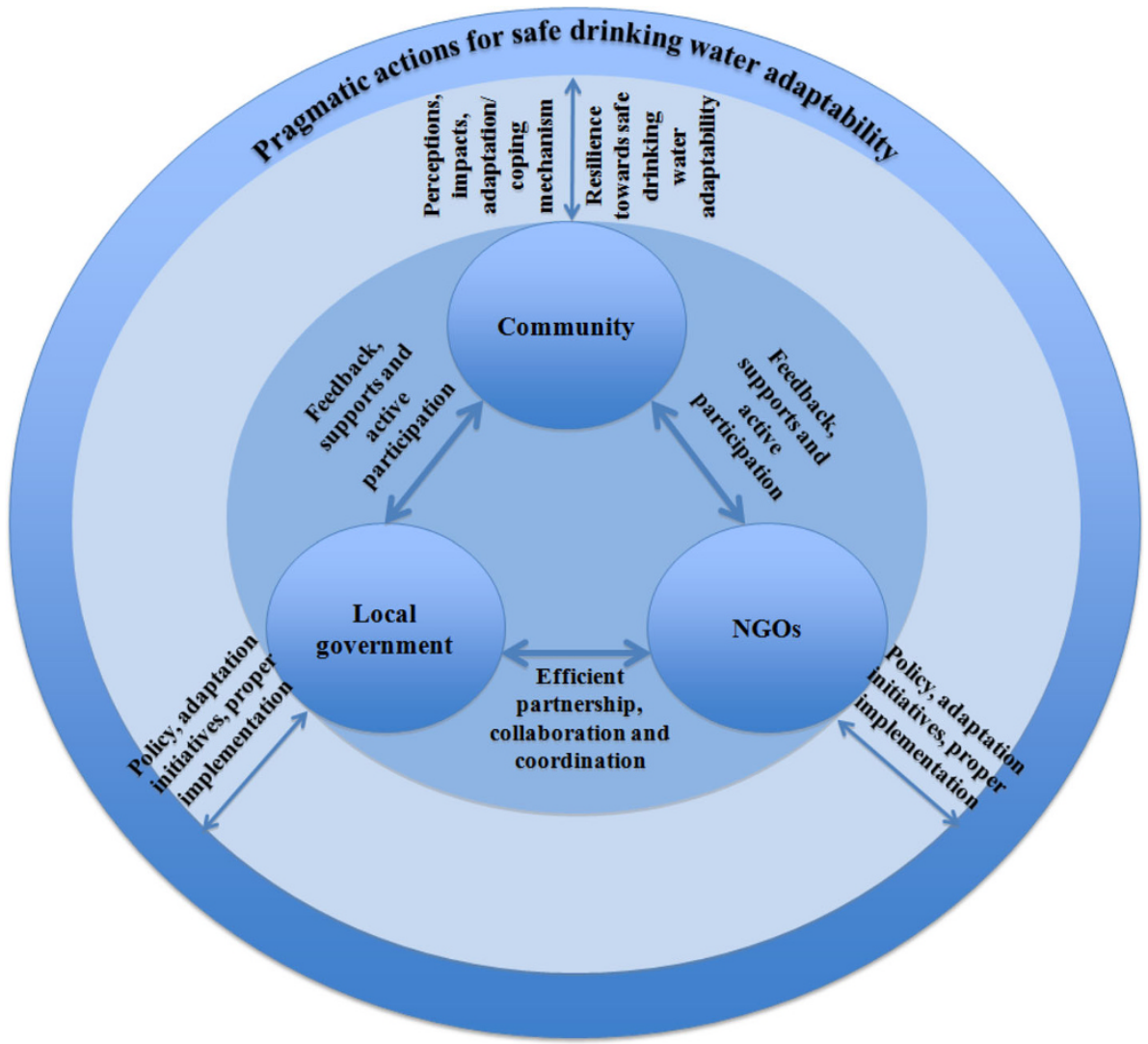

is imperative that communities' adaptation methods be supported and guided by local governments and NGOs to make them both more effective and environmentally friendly (Parvin et al. 2008). At the same time, it is imperative to have efficient partnerships, collaboration, and coordination between government organizations and NGOs (Habiba et al. 2011).

This study identifies and reveals people's perception on safe drinking water scarcity with regard to salinity, arsenic, and drought as well as the adaptation measures they currently employ to cope with the above-mentioned hazards that are directly or indirectly responsible for drinking water scarcity. It also discusses communities' expected support from various organizations. The results of this study reveal that salinity along with arsenic contamination play key roles in making the study area vulnerable to safe drinking water scarcity, which is aggravated by and becomes acute during dry periods. A number of socioeconomic factors along with geographical location enhance the vulnerability of individuals and communities in the study area and relentlessly undermine the struggle of people to minimize or cope with their vulnerabilities by undertaking adaptive measures. This study highlights how communities need to improve their critical situation in both the severe and moderate drinking water scarcity areas. The results reveal that rainwater harvesting is the prime demand in the severe drinking water scarcity area, whereas piped water supply is the preferred expectation for moderate drinking water scarcity areas. Undertaking actions at the community level requires government as well as other organizational initiatives and activities to implement these actions. Rather than disaggregated efforts, integration is needed to resolve the potable water supply problem and to facilitate a community's adaptation. Although a number of government and nongovernment organizations are working at both the local and the national levels, the main problem is a lack of coordination among them. Because there is no integrated approach between adaptation measures of the community, government, and other development organizations, it is difficult to overcome drinking water scarcity. The National Water Policy of the Bangladesh government should incorporate methods of coordination and partnership among the development efforts of government, NGOs, and communities in order to insure proper implementation at the grassroots level. This would promote pragmatic actions that facilitate integration by knowing and applying community perception, adaptation measures, and expectations to cope with and solve the safe drinking water scarcity problem.

Acknowledgments The authors gratefully acknowledge support from the Japan Society for the Promotion of Science (JSPS) for this 
research. Help and cooperation of the local community and stakeholders are also greatly appreciated.

Open Access This article is distributed under the terms of the Creative Commons Attribution License which permits any use, distribution, and reproduction in any medium, provided the original author(s) and the source are credited.

\section{References}

Abedin, M.A., and R. Shaw. 2013a. Safe water adaptability for salinity, arsenic and drought risks in southwest of Bangladesh. Risk, Hazards and Crisis in Public Policy 4(2): 62-82.

Abedin, M.A., and R. Shaw. 2013b. Arsenic contamination in Bangladesh: Contemporary alarm and future strategy. In Disaster risk reduction approaches in Bangladesh, ed. R. Shaw, F. Mallick, and A. Islam, 191-216. Tokyo: Springer.

Abedin, M.A., and R. Shaw. 2013c. Community level arsenic mitigation practices in southwestern part of Bangladesh. In Water insecurity: A social dilemma, ed. M.A. Abedin, U. Habiba, and R. Shaw, 51-73. Bingley, UK: Emerald Publishers.

Abedin, M.A., U. Habiba, and R. Shaw. 2012. Impacts of salinity, arsenic and drought in south-western Bangladesh. In Environment disaster linkages, ed. R. Shaw, and T. Phong, 165-193. Bingley, UK: Emerald Publishers.

Abedin, M.A., U. Habiba, and R. Shaw (eds.). 2013. Water insecurity: A social dilemma. Bingley, UK: Emerald Publishers.

Agrawala, S., T. Ota, A.U. Ahmed, J. Smith, and M. van Aalst. 2003. Development and climate change in Bangladesh: Focus on coastal flooding and Sundarbans. Paris: OECD (Organization for Economic Co-operation and Development).

Ahmed, A.U. 2008. Desakota phenomenon observed in SatkhiraKhulna-Jessore-Dhaka corridor in the southwestern Bangladesh: A case study in re-imagining the rural-urban continuum. Kathmandu, Nepal: Desakota Study Team, Institute for Social and Environmental Transition (ISET).

Ali, A.M.S. 2006. Rice to shrimp: Land use/land cover changes and soil degradation in southwestern Bangladesh. Land Use Policy 23(4): 421-435.

Appelo, T. ed. 2006. Arsenic in groundwater: A world problem. Proceedings of a seminar organized by the Netherlands National Committee of IAH (International Association of Hydrogeologists), Publication No. 5. Utrecht, The Netherlands, IAH. http://www. un-igrac.org/dynamics/modules/SFIL0100/view.php?fil_Id=107. Accessed 8 Jun 2014

Borghesi, S., and A. Vercelli. 2005. Global health. http://www.aiccon. it/file/convdoc/n.13.pdf. Accessed 9 May 2014.

Chowdhury, M.R. 2007. Rainfall variability: Impacts of climate change? http://www.southasianfloods.icimod.org/. Accessed 9 May 2014.

Concern Worldwide. 2012. Water: How can we increase the world's access to clean water. New York: Concern Worldwide US.

Curry, E. 2010. Water scarcity and the recognition of the human right to safe freshwater. Northwestern Journal of International Human Rights 9(1): Article 5.

Daily Star. 2013. Salinity in southwestern region: Drinking water to death. 26 July 2013.

Dankelman, I., K. Alam, A. Khurshid, W.B. Ahmed, Y.D. Gueye, N. Fatema, and R.M. Kutin. 2008. Gender, climate change and human security: Lessons from Bangladesh, Ghana and Senegal. Report prepared for Hellenic Foundation for European and Foreign Policy (ELIAMEP) by the Women's Environment and Development Organization (WEDO), ABANTU for Development in Ghana, Action Aid Bangladesh, and ENDA in Senegal.
Farhana, S. 2011. Suitability of pond sand filters as safe drinking water solution in storm surge prone areas of Bangladesh: A case study of post-AILA situation in Shyamnagar, Satkhira District, Khulna. Master's Thesis. Postgraduate Programs in Disaster Management (PPDM), BRAC University, Dhaka, Bangladesh.

Gain, P. 1995. Attack of the shrimps. TWR 59: 18-19.

Gopal, B., and M. Chauhan. 2006. Biodiversity and its conservation in the Sundarban mangrove ecosystem. Aquatic Sciences 68(3): $228-254$.

Habiba, U., and R. Shaw. 2012. Bangladesh experiences of community based disaster disk reduction. In Community, environment and disaster risk management, ed. R. Shaw, 91-111. Bingley, UK: Emerald Publishers.

Habiba, U., R. Shaw, and Y. Takeuchi. 2011. Drought risk reduction through a socio-economic, institutional and physical approach in the northwestern region of Bangladesh. Environmental Hazards 10(2): 121-138.

Habiba, U., R. Shaw, and Y. Takeuchi. 2012. Farmer's perception and adaptation practices to cope with drought: Perspectives from northwestern Bangladesh. International Journal of Disaster Risk Reduction 1: 72-84.

Habiba, U., M.A. Abedin, and R. Shaw. 2013. Salinity induced livelihood stress in southwestern part of Bangladesh. In Water insecurity: A social dilemma, ed. M.A. Abedin, U. Habiba, and R. Shaw, 139-165. Bingley, UK: Emerald Publishers.

Hadi, A., and R. Parveen. 2004. Arsenicosis in Bangladesh: Prevalence and socio-economic correlates. Public Health 118(8): 559-564.

Hoque, R.M. 2009. Access to safe drinking water in rural Bangladesh: Water governance by DPHE. Master's Thesis, Institute of Governance Studies, BRAC University, Dhaka, Bangladesh.

Horneman, A., A. van Green, D. Kent, P.E. Mathe, Y. Zheng, R.K. Dhar, et al. 2004. Decoupling of As and Fe release to Bangladesh groundwater under reducing conditions. Part 1: Evidence from sediment profiles. Geochimica et Chosmochimica Acta 68(17): 3459-3473.

Islam, R.M. (ed.). 2004. Where land meets the sea: A profile of the coastal zone of Bangladesh. Dhaka: University Press Limited.

Islam, M.R. 2008. Towards institutionalization of global ICZM efforts. In Integrated coastal zone management, ed. R.R. Krishnamurthy, A. Kannen, A. Ramanathan, S. Tinti, B.C. Glavovic, D.R. Green, Z. Han, and T.S. Agardy, 23-34. Singapore: Research Publishing.

Islam, N., and A. Gnauck. 2008. Mangrove wetland ecosystems in Ganges-Brahmaputra Delta in Bangladesh. Frontiers of Earth Science in China 2(4): 439-448.

Islam, M.M., F.N.F. Chou, M.R. Kabir, and C.H. Liaw. 2010. Rainwater: A potential alternative source for scarce safe drinking and arsenic contaminated water in Bangladesh. Water Resources Management 24(14): 3987-4008.

Kamruzzaman, A.K.M., and F. Ahmed. 2006. Study of performance of existing pond sand filters in different parts of Bangladesh. In Sustainable development of water resources, water supply and environmental sanitation, 32nd WEDC (Water, Engineering and Development Centre) conference, Colombo, Sri Lanka, 13-17 November 2006, 377-380. Colombo: WEDC Publications.

Marfai, M.A., L. King, J. Sartohadi, S. Sudrajat, R.S. Budiani, and F. Yulianto. 2008. The impact of tidal flooding on a coastal community in Semarang, Indonesia. The Environmentalist 28(3): 237-248.

Miah, M.M.U. 2010. Assessing long-term impacts of vulnerabilities on crop production due to climate change in the coastal areas of Bangladesh. Bangladesh Center for Advanced Studies, Final Report PR \#10/08.

Ministry of Environment and Forest, Bangladesh. 2005. National adaptation program of action. Dhaka: Ministry of Environment and Forest, Government of the People's Republic of Bangladesh. 
Ministry of Water Resources, Bangladesh. 2005. Coastal zone policy. Dhaka: Ministry of Water Resources, Government of the People's Republic of Bangladesh.

Mirza, M.M.Q. (ed.). 2004. The Ganges water diversion environmental effects and implications. Dordrecht: Kluwer Academic Publishers.

MoWR (Ministry of Water Resources), Bangladesh. 2006. Coastal development strategy. Dhaka: Water Resources Planning Organizations, Ministry of Water Resources, Government of People's Republic of Bangladesh.

Parvin, G.A., F. Takahashi, and R. Shaw. 2008. Coastal hazards and community-coping methods in Bangladesh. Journal of Coastal Conservation 12(4): 181-193.

Pereira, L.S., L. Cordery, and L. Lacovides. 2009. Coping with water scarcity: Addressing the challenges. New York: Springer.

Quazi, A.R. (ed.). 2006. In search of safe drinking water: In the context of climate change and salinity. Satkhira, Bangladesh: Uttaran and Water Committee.

Shaw, R., and D. Thaitakoo. 2010. Water communities: Introduction and overview. In Water communities, ed. R. Shaw, and D. Thaitakoo, 1-13. Bingley, UK: Emerald Publishers.
Swapan, S.S.A., and M.M. Mamun. 2006. In search of safe drinking water: In the context of climate change and salinity. Uttaran, Tala, Satkhira, Bangladesh. http://uttaran.net/publications/ insearchofsafedrinkingwater.pdf. Accessed 9 May 2014.

Tho, N., N. Vromant, N.T. Hung, and L. Hens. 2008. Soil salinity and sodicity in a shrimpfarming coastal area of the Mekong Delta, Vietnam. Environment Geology 54: 1739-1746.

WHO (World Health Organization). 2008. An interview with Mahmudur Rahman: Bangladesh arsenic agony. Bulletin of the World Health Organization 86(1): 11-12.

WHO (World Health Organization) and UNICEF (United Nations Children's Fund). 2010. Estimates for the use of improved drinking water sources and improved sanitation facilities. Geneva: World Health Organization and United Nations Children's Fund, Joint Monitoring Program for Water Supply and Sanitation.

Wijayaratna, D.M. 2004. Role of local communities and institutions in integrated rural development. Asian productive organization. http://www.apo-tokyo.org/publications/files/pjrep-icd-se-3-01. pdf. Accessed 14 May 2014. 